DOI: $10.2478 / \mathrm{v} 10025-010-0010-0$

JOURNAL OF WATER

AND LAND DEVELOPMENT

J. Water Land Dev. No. 13b, 2009: 137-147

\title{
Lacustrine deposits in northern part of the Knyszyńska Forest - the remains of water bodies
}

\author{
Krzysztof MICUN
}

Department of Environmental Protection and Management, Białystok Technical University, Wiejska 45a Street, 15-351 Białystok, Poland; micun@pb.bialystok.pl

\begin{abstract}
The aim of this study was to delimit lacustrine deposits underlaying present peatlands. On this basis, the location of water bodies in late Pleistocene and early Holocene was recognized. The lakes' occurrence was presented on the background of geomorphological conditions.

Lacustrine deposits occur mainly in depressions of the northern part of the Knyszyńska Forest. They are placed in upper parts of the Czapielówka River, Jałówka River, middle Sokołda River and upper Kumiałka River catchments. The thickness of gyttja varies between 0.4 and $2.5 \mathrm{~m}$. These are detrital, calcareous and clay-calcareous gyttjas. Lacustrine sediments fill the bottoms of various meltout depressions. The origin of these depressions, as well as the whole glacial relief of the terrain, is often linked to deglaciation of the Warta ice sheet. However, kame deposits in the Janów village are younger than Warta glaciation. Moreover, the catchment relief of the upper Kumiałka River is similar to the relief which originates from Vistulian glaciation. Besides, there are boulder deposits directly under the lacustrine deposits. These three facts indicate a younger age of the melt-out depressions in the upper Kumiałka River catchment.
\end{abstract}

Key words: the Knyszyńska Forest, the Late Pleistocene lakeland, lacustrine deposits, peatlands

\section{INTRODUCTION}

The landscape of the Knyszyńska Forest changed in time and the present state does not resemble the one which was left in this area after the glacial epoch. The appearance and disappearance of water bodies there in the late Pleistocene and in the early Holocene were a significant stage of shaping the scenery of the Knyszyńska Forest. The existence of water reservoirs in the Knyszyńska Forest at the turn of Pleistocene and Holocene was confirmed by subsidence of the following peatlands: Machnacz (KUPRYJANOWICZ, 1991; ŻUREK, 1992), Stare Biele (ŻUREK, 2000), Taboły and Kładkowe Bagno (DRZYMULSKA, 2006; 2008; KUPRYJANOWICZ, 2007; 2008; KUPRYJANOWICZ and DRZYMULSKA, 2008). Such lakes 
probably existed from Alleröd and Younger Dryas (DRZYMULSKA, 2006; KUPRYJANOWICZ and DRZYMULSKA, 2008; STASIAK, 1979) and could remain to the beginning of the Holocene (Preboreal, Boreal) (DRZYMULSKA, 2006) or even to the end of the Atlantic period (KUPRYJANOWICZ and DRZYMULSKA, 2008; ŻUREK, 1992).

The bottom of the lacustrine deposits in the Taboly peatland was dated as Younger Dryas (DRZYMULSKA, 2006). According to KUPRYJANOWICZ (2008), the origin of water bodies is linked with thermokarst processes and possibly connected with Eemian organic deposits compaction. These deposits are covered with mineral sediments.

Present study is an attempt to determine the spatial range of water reservoirs in the northern part of the Knyszyńska Forest in the late Pleistocene and to recognise geomorphological conditions of their existence.

The results presented here have a preliminary character and the full explanation of the origin and functioning of water bodies in the Knyszyńska Forest requires detailed, mainly sedimentological investigations.

\section{MATERIALS AND METHODS}

Paleo-geographical reconstruction was based on the occurrence of gyttja layers in numerous depressions, which formed as a result of sedimentation in small lakes. The study area was the northern part of the Knyszyńska Forest (north of Czarna Białostocka) which included upper fragments of the Czapielówka River, Jałówka River and Kumiałka River catchments (Fig. 1).

The extent of gyttja was reconstructed based on drillings. Drillings were made using a drill with an Instorf-type container of $50 \mathrm{~mm}$ diameter. Almost one hundred drillings were made. They reached the mineral bottom (maximum $4.5 \mathrm{~m}$ depth). The number of drillings and their location depended on the size of depressions and on local terrain situation. There were 11 drillings in Jesionowe Góry, 13 in Rosiczka, 16 in Szerokie Łąki, 6 in a peatland near Młynowa street, 24 in Sosnowe Bagno and 28 in Stare Brody. Representative samples of organic deposits were subjected to the analysis of macrofossils. The approximate range of water bodies in the late Pleistocene and the older Holocene was determined based on the location of gyttjas.

Twenty nine geomorphological exposures were analysed in the areas surrounding depressions. On this basis the structure of landforms was described and afterwards geomorphological survey was performed. Detailed geomorphological maps of the surroundings of Czarna Białostocka and the Sosnowe Bagno village were made in the scale 1:10 000. These maps enabled presentation of geomorphological conditions of water reservoirs in late Pleistocene and in early Holocene in the northern part of the Knyszyńska Forest. 


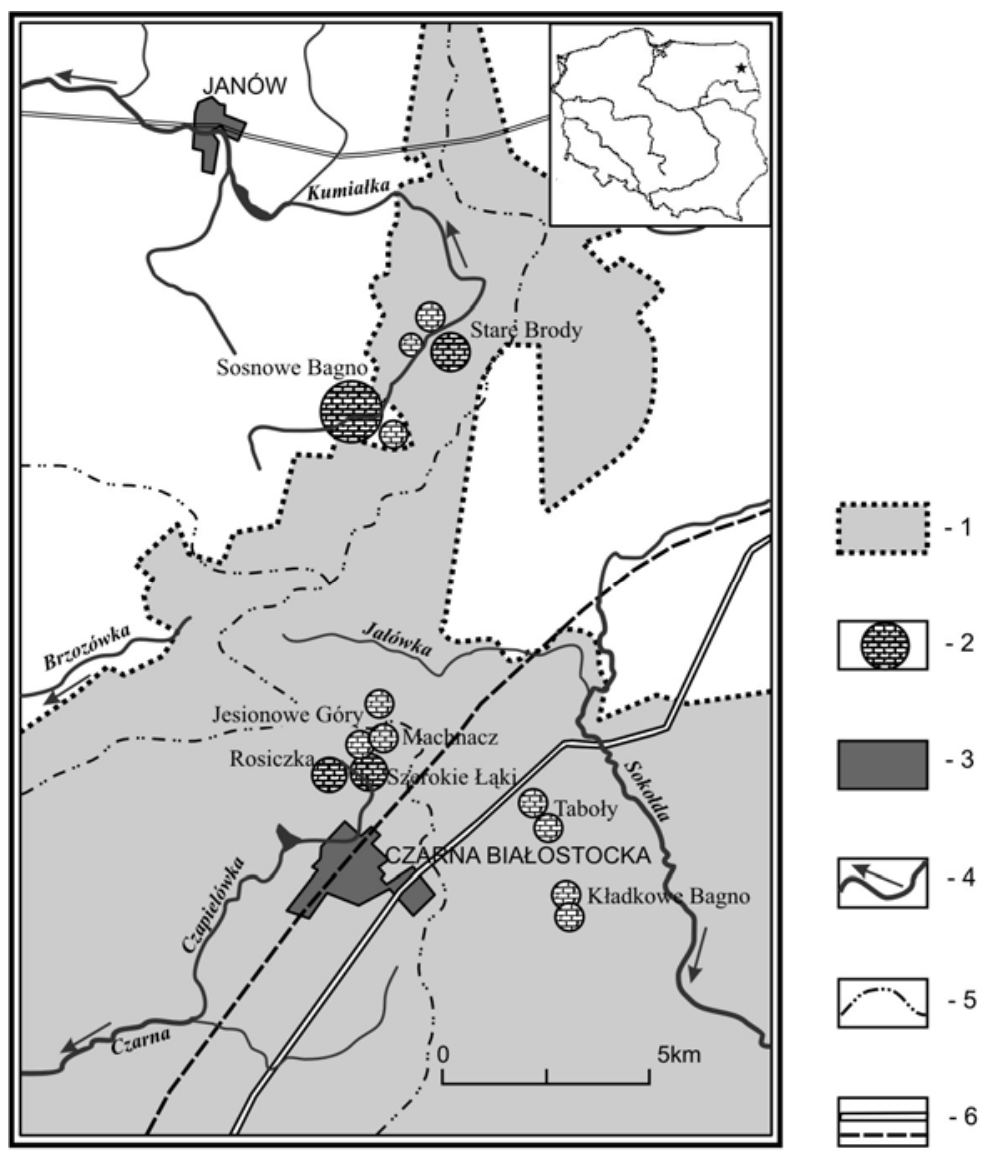

Fig. 1. Location of the gyttja deposits within the borders of the Knyszyńska Forest; 1 - the area of the Knyszyńska Forest, 2 - places of the occurrence of lacustrine deposits, 3 - larger localities, 4 - rivers, 5 - watersheds, 6 - roads and railways

Archival soil mechanics and pedological materials (documentation of technical study of grounds in the Stare Brody range (KARDASZ, 1984) and soilagricultural maps of Sosnowe Bagno, Ostrynka and Rudawka areas in the scale 1:5 000) were also used in the study.

\section{RESULTS AND DISCUSSION}

Lacustrine deposits adjacent to Czarna Białostocka were found in the peatland Taboły and Kładkowe Bagno, in central part of the Sokołda River catchment (DRZYMULSKA, 2006; 2008). In the Taboły peatland these deposits were built of lake lime and calcareous gyttja. The thickness of calcareous mud varied between 
0.2 and $0.5 \mathrm{~m}$, while an average thickness of calcareous gyttja was $0.2 \mathrm{~m}$. The calcareous gyttja and detrital gyttja occured in the peatland situated in the Jesionowe Góry reserve (Machnacz B) in the spring zone of the Czapielówka stream (ŻUREK, 1992).

The author's own study enabled to delimit the probable borders of water bodies in this depression (Fig. 2). Drillings in the middle part of Jesionowe Góry peatland revealed organic sediments whose thickness reached $3.3 \mathrm{~m}$. Sphagnum-

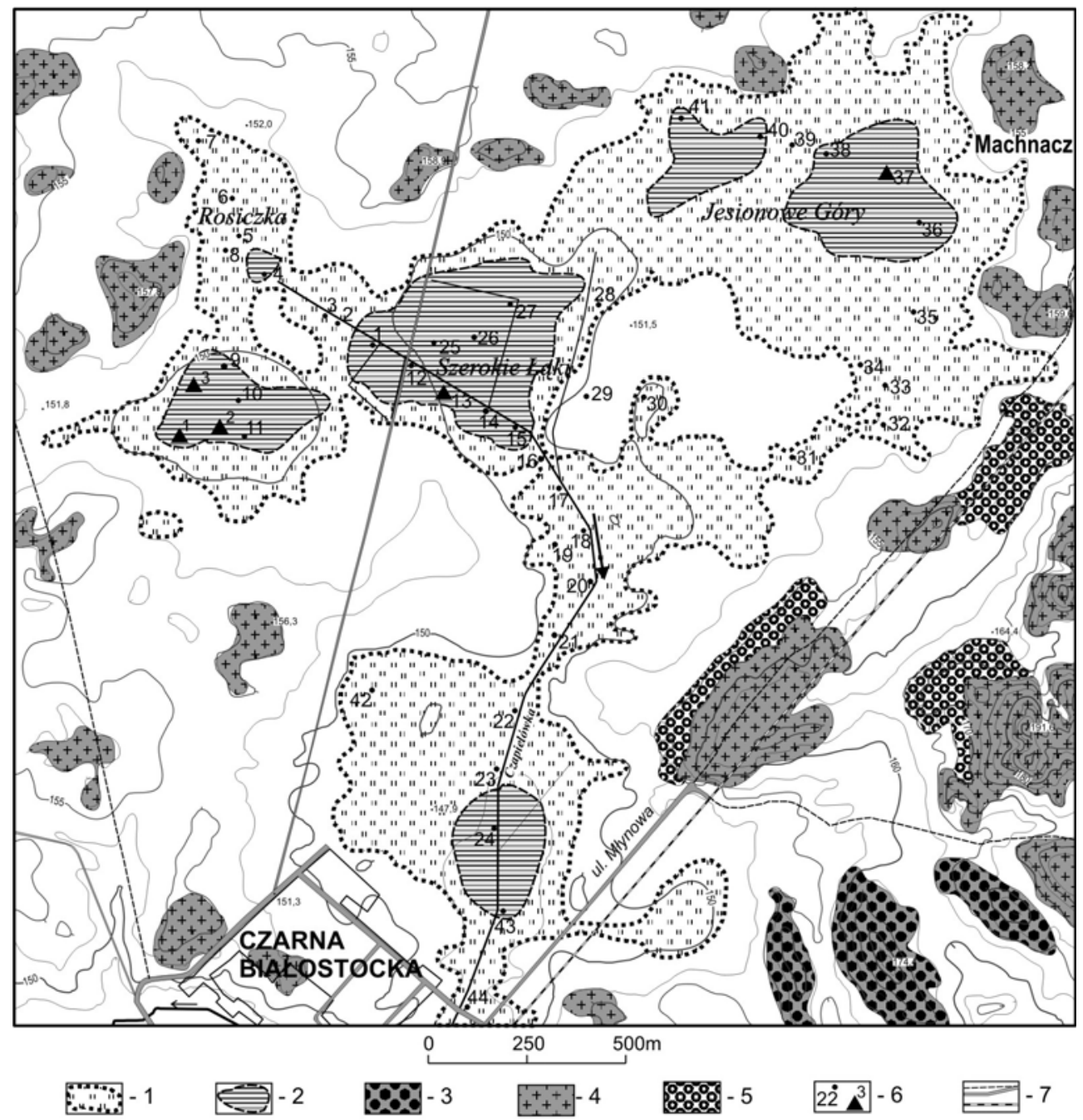

Fig. 2. Probable range of water bodies between Czarna Białostocka and the Machnacz village; 1 - the borders of peatlands, 2 - range of gyttja deposits - probable range of reservoirs, 3 - crevice forms, 4 - kames, 5 - kame terraces, 6 - the bore-holes including those presented in Fig. 3, 7 - the roads and railways 
-Cottongrass peats were present there to the depth of $170 \mathrm{~cm}$ with decomposition degree increasing with depth. This peat is underlain by the layer of medium decomposed moss peat and reed-moss peat of a total thickness of $0.9 \mathrm{~m}$. Gyttja's thickness reached $0.6 \mathrm{~m}$. At depths from $2.7 \mathrm{~m}$ to $3.2 \mathrm{~m}$ the olive brown detrital gyttja was present underlain by blue beige loamy gyttja (Fig. 3).

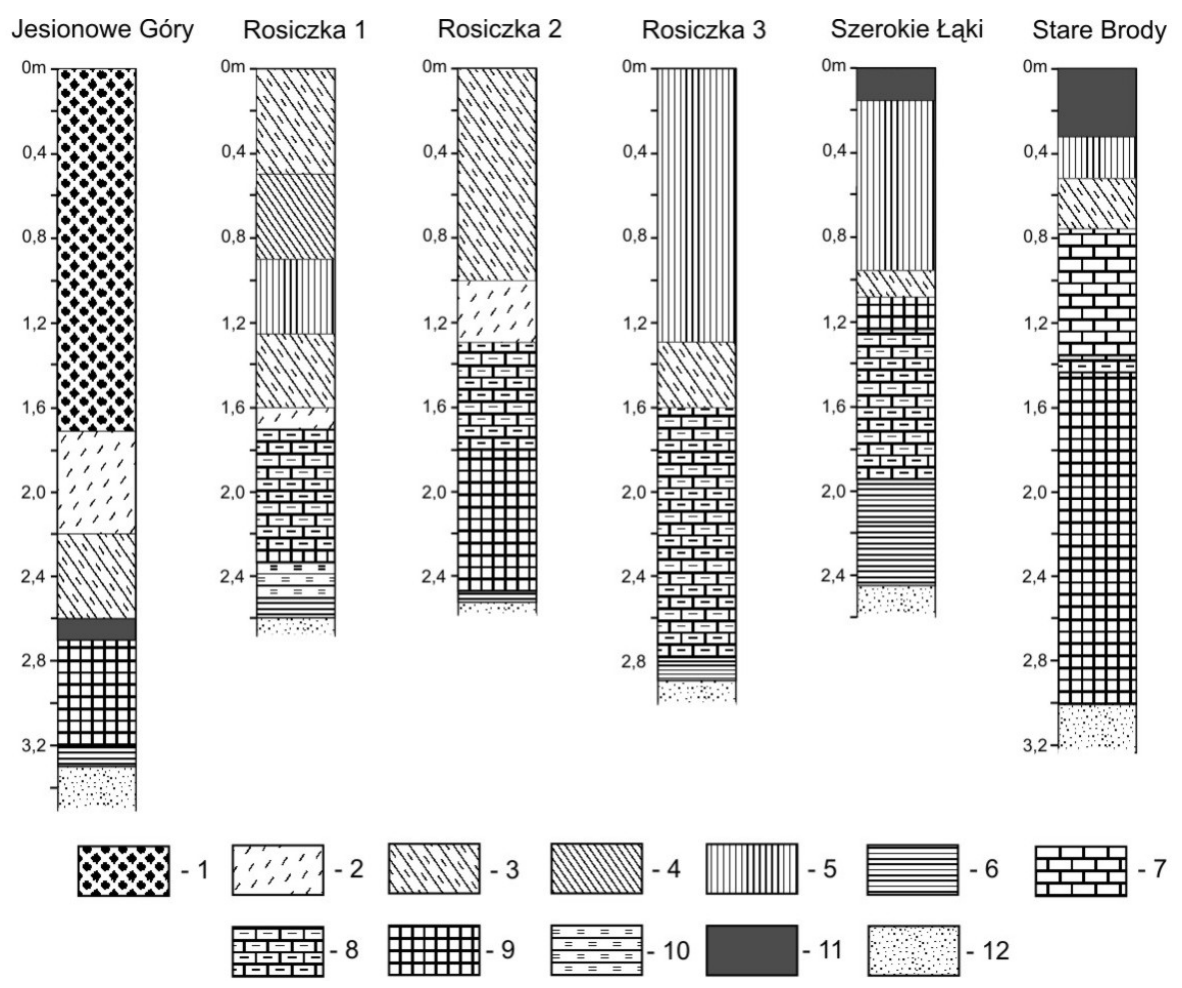

Fig. 3. Selected profiles of the bore-holes from peatlands of the northern part of the Knyszyńska Forest; 1 - Sphagnum and transition peats, 2 - moss peat, 3 - reed- and sedge-moss peat, 4 - reed peat, 5 - forest peat and sedge-forest peat, 6 - clay gyttja, 7 - calcareous gyttja, 8 - clay-calcareous gyttja, 9 - detrital gyttja, 10 - detrital-calcareous gyttja, 11 - amorphous peat, 12 - mineral bottom

Gyttjas were also present at the bottom of Szerokie Laki peat deposit and in the peatland near Młynowa street in Czarna Białostocka (MICUN, 2006). Mineralcalcareus gyttja occured on sandy subsoil. Its thickness reached $0.35 \mathrm{~m}$ at most and the thickness of overlaying detrital gyttja of olive colour reached $2 \mathrm{~m}$.

At the bottom of the Rosiczka peatland situated west of Szerokie Laki, gyttjas filled quite vast substratum's lowering stretching almost latitudinally towards Szerokie Laki (Fig. 2). In the central part of this lowering, gyttja's thickness exceeded $2 \mathrm{~m}$ and decreased gradually towards the edges where its thickness varied between 1.3 and $1.6 \mathrm{~m}$. A $10 \mathrm{~cm}$ deep layer of blue grey clay gyttja overlain the unequal 
grain size sands at a depth of 2.6-2.9 m. It was covered by detrital and clay - calcareous gyttja of olive or olive beige colours, whose thickness reached $1.5 \mathrm{~m}$. The content of calcium carbonate in these formations varied between 21 and 23\%.

Peatlands in Jesionowe Góry, Szerokie Łaki, Rosiczka or Taboły are parts of the vast melt-out depression, stretching downstream of the Sokołda River and its tributary - the Jałówka River (BANASZUK, 1995). An object near Młynowa street is a small melt-out basin. Melt-out depressions are surrounded by ground moraine built of tills in its northern and southern part and of glacial sands in its eastern and western part (MICUN, 2006). Small kame knolls and crevice forms rise above the surface of the moraine. They are built of sands and fine gravel stratified diagonally or horizontally, usually with a high degree of selection. South-east of the melt-out basin near Młynowa Street three banks are situated meridionally. They are built of stratified gravels. These are crevice forms (Fig. 2). The kame terrace neighbours the depression from east (MICUN, 2006). Described landforms originate from Warta's glaciation (BANASZUK, 1995; MICUN, 2006; MUSIAE, 1992). Therefore, the depressions functioned already in Eemian, however organic deposits from that period were found only in the northern peatland Machnacz in the Jałówka River catchment (KUPRYJANOWICZ, 1991; ŻUREK, 1992).

Gyttja was also found in the lowering of the upper Kumiałka River valley (MICUN, 1996). Studies performed in this region in 2008 enabled to specify the range of lacustrine deposits. Bore-holes were drilled near the Sosnowe Bagno village. Gyttja in this lowering occupied the area of over 70 ha, spreading from west to the peatland's centre (Fig. 4). The thickness of these formations was low and reached $0.45 \mathrm{~m}$ at most. It was white and grey clay - calcareous gyttja. Its range in the western direction is larger than found before (MICUN, 1996). Gyttja also filled smaller lowerings in the eastern part of the melt-out depression near Stoczki (Fig. 4).

Gyttjas in the exact Stare Brody range had the greatest thickness of all found in this region of the Knyszyńska Forest and reached $2.5 \mathrm{~m}$. Drillings in the central part of Stare Brody range revealed organic deposits $3 \mathrm{~m}$ thick (Fig. 3). They covered unequal grain size sands with galets. Olive brown highly compacted sandy gyttja of $0.6 \mathrm{~m}$ thickness directly overlay the subsoil. It was covered by the dark olive detrital gyttja whose thickness reached $0.85 \mathrm{~m}$. A thin layer of olive calcareous - detrital gyttja with frequent shells was found above it. It was covered by olive beige calcareous - detrital gyttja $(0.3 \mathrm{~m})$ with shells. White beige calcareous gyttja occurred at a depth of $75-115 \mathrm{~cm}$. Peat is the last link of organic sedimentation: $25 \mathrm{~cm}$ of moss peat with pieces of wood, $20 \mathrm{~cm}$ russet black alder swamp forest peat and $30 \mathrm{~cm}$ of muck (Fig. 3). A very interesting was the fact that calcareus gyttja was situated above detrital gyttja, which may suggest the deepening of the reservoir that took place later or accumulation in a cooler period with a weak development of vegetation. 


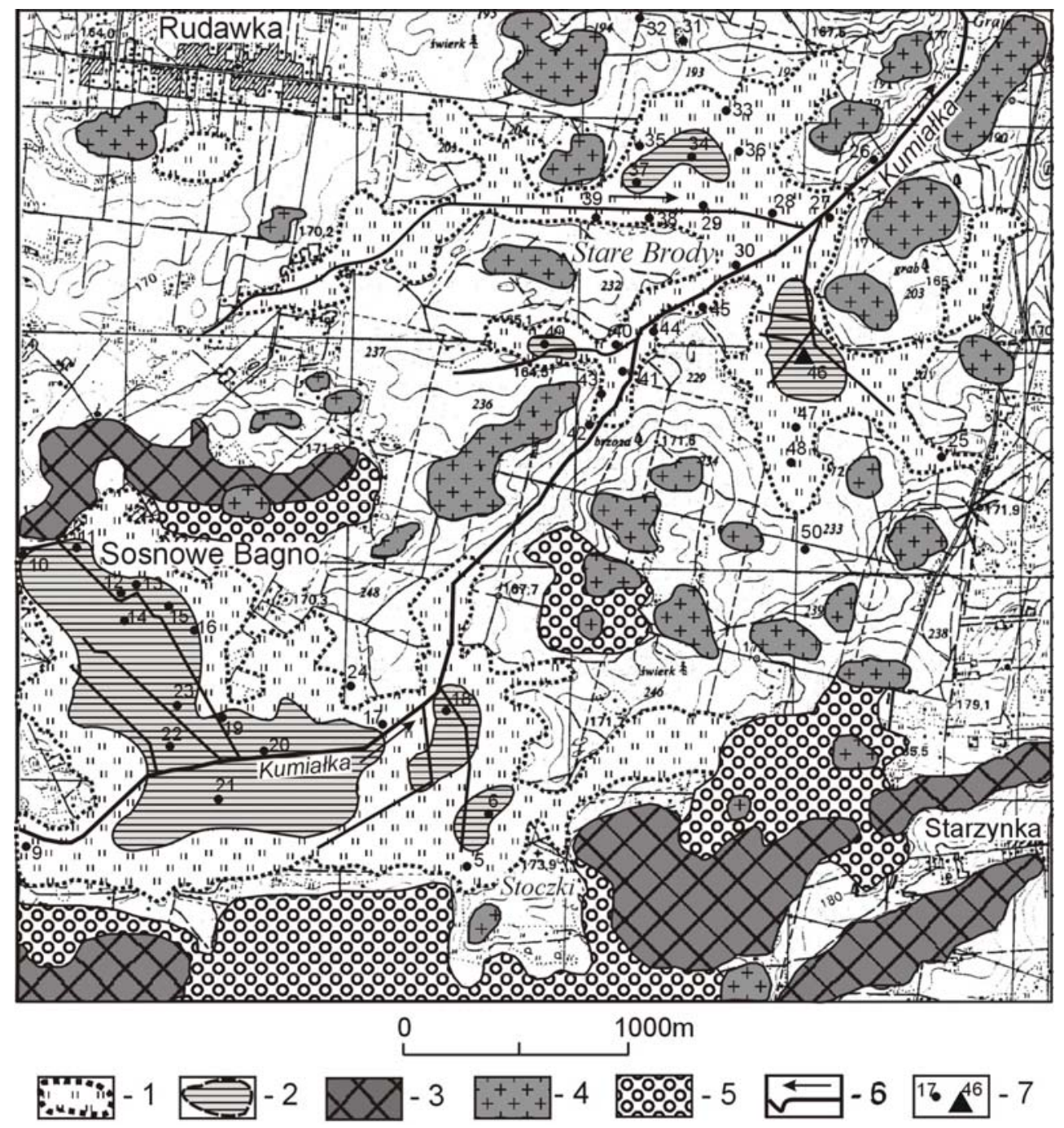

Fig. 4. Location of lacustrine deposits in the object Stare Brody, with the most important landforms; 1 - range of organic sediments in the bottoms of melt-out depressions, 2 - range of the occurrence of gyttja - probable borders of water reservoirs, 3 - the dead-ice moraines, 4 - kames, 5 - kame terraces, 6 -watercourses, 7 - the bore-holes including those presented in Fig. 3

The gyttja - type sediments were found at the bottoms of various kinds of depressions of melt-down origin. Lowerings in the upper section of the Kumiałka River valley are the examples of melt-outs with classically developed forms of the glacial and glacifluvial accumulation. The lowering near the Sosnowe Bagno village is surrounded from south, west and north by arched stretched elevations of the maximum height around $181 \mathrm{~m}$ a.s.l. These formations were categorized by 
MUSIAE (1992) as kame banks. The analysis of morphological features of these formations and their structure, and the occurrence of badly sorted thick material of a diameter up to $30 \mathrm{~cm}$ and sometimes also clays enabled to recognise them as the dead-ice moraines. Between Sosnowe Bagno and Stare Brody lowerings the meridional elevations are situated of a relative height of up to $15 \mathrm{~m}$ built of sands and stratified fine gravels. These are kame banks. Kames of a similar structure are situated east and south west of the lowering. Kame terraces 5-6 m high built of gravel and sand neighbour the dead-ice moraines. The remaining part of the terrain is occupied by the ground moraine built of tills and glacial sands. The lowering of Stare Brody range is shaped irregularly and is surrounded by kame elevations of a relative height of up to $10 \mathrm{~m}$.

It is a common belief that the glacial relief of these areas comes from the period of the Warta glaciation (MUSIAE, 1992). However, certain facts suggest the possibility of the younger origin of post-glacial landforms. In melt-out depressions directly under organic deposits, ablational and glacial sediments appear and neither deluvial nor other interglacial deposits were found there. The relief morphologically refers to the lower levels of Wysoczyzna Białostocka, whose origin is linked with the activity of ice-sheet of the Świecie stage of the Vistulian glaciation (BANASZUK, 2004). Thermoluminescence dating (TL) of kame deposits in nearby Janów may indicate a younger than Warta glaciation origin of deposits. Their age is $56.5 \pm 8.5 \mathrm{ka}$ (UG-5827).

Considering the facts mentioned above the late Pleistocene and early Holocene origin of water reservoirs is not clear. It is worth to notice that these reservoirs did not have classically developed lake basins. They were more of a flood waters type, particularly larger reservoirs at Sosnowe Bagno, Szerokie Łąki and Rosiczka. Their similarity to lakes existing in that time in the Biebrza River Valley is noticeable (BANASZUK, 1980; ŻUREK, 1991).

\section{CONCLUSIONS}

Analysed lowerings are currently filled by peatlands of all types: raised bogs Jesionowe Góry and Taboły, transition bogs - Rosiczka and Kładkowe Bagno and low moors - Stare Brody, Sosnowe Bagno, Szerokie Łaki. They are in various stages of development, accumulation or the decession phase. Regardless of the present-day condition of peatland, the deposits of various thickness and origin at their bottoms were found.

Commonly found gyttjas at the bottoms of melt-out depressions indicate the existence of numerous, small water bodies in the northern part of the Knyszyńska Forest, in late Pleistocene and in early Holocene. The thickness of lacustrine deposits exceeds $2 \mathrm{~m}$ in many places, which proves that water bodies were the element of the landscape for relatively long period of time. 
All water reservoirs came into being and functioned at the bottoms of the various kinds of melt-out lowerings. The origin of melt-out forms and the whole glacial relief in Czarna Białostocka's neighbourhood is connected with the deglaciation of Warta glaciation. The age of melt-out depression situated more north towards Janów arises more doubts though.

The age of kame deposits in Janów, relief's reference to lower and younger morphological levels and the occurrence of ablation and glacial sediments directly under lacustrine deposits suggest Vistulian age of melt-outs situated in the upper part of the Kumiałka River catchment.

Because of unequal age of melt-out water depressions and flood waters character of some water bodies of that time the phenomena of thermokarst and compaction of Eemian organic deposits do not completely justify the origin of late Pleistocene and early Holocene lakes in the northern part of Knyszyńska Forest. The full explanation of the origin of water reservoirs from this period requires more detailed investigations.

The financial support was provided by Ministry of Science and Higher Education within the project $\mathrm{S} / \mathrm{IIS} / 21 / 08$.

\section{REFERENCES}

1. BANASZUK H., 1980. Geomorfologia południowej części Kotliny Biebrzańskiej. (Geomorphology of southern part of the Biebrza Valley). Pr. St. Geogr., 2. Warszawa, Wydaw. UW.

2. BANASzuK H., 1995. Geneza i rozwój rzeźby terenu Puszczy Knyszyńskiej w świetle analizy geomorfologicznej i analiz termoluminescencyjnych. W: Puszcza Knyszyńska. Monografia przyrodnicza. (Origin and development of land relief of Knyszyńska Forest in view of geomorphological and thermo-luminescent analyses). Ed. A. Czerwiński. Supraśl, Zesp. Park. Krajobr.: 33-49.

3. BANASZUK H., 2004. Główne rysy rzeźby terenów związanych genetycznie ze zlodowaceniem Wisły na nizinie Północnopodlaskiej: W: Zlodowacenia i interglacjały wschodniej Polski, problemy plejstocenu Wysoczyzny Białostockiej. (Main features of land relief genetically associated with Vistulian glaciation in Północnopodlaska lowland. In: Glaciations and interglacial periods of eastern Poland, problems of the Pleistocene on Białostocka Upland). Warszawa, Wydaw. PIG: $14-16$.

4. DrZyMulska D., 2006. The Late Glacial and Holocene water bodies of Taboły and Kładkowe Bagno mires (Puszcza Knyszyńska Forest): genesis and development. Limnol. Rev., 6: 73-78.

5. DRZYMULSKA D., 2008. Development of the Kładkowe Bagno peat bog in the Late Glacial and Holocene: diversified history of two deposit Basins studied with use of macrofossil remains analysis. St. Quartenaria, 25: 23-32.

6. DrZYMUlska D., KupRYjanOwicz M., 2008. Zarys paleoekologii torfowisk Puszczy Knyszyńskiej. W: Różnorodność badań botanicznych - 50 lat Białostockiego Oddziału Polskiego Towarzystwa Botanicznego 1958-2008. (An outline of peatland paleo-ecology in the Knyszyńska Forest. In: Diversity of botanical studies - 50 years of Białystok Branch of the Polish Botanical Society 1958-2008) Ed. K. Kolanko. Białystok, Fund. Ekon. Środ. Zasobów Nat., PTB: 168-179.

7. ILNICKI P., 2002. Torfowiska i torf. (Peatlands and peat). Poznań, Wydaw. AR: 606. 
8. KARDASZ J., 1984. Obiekt Stary Bród. Dokumentacja z technicznych badań podłoża gruntowego. Projekt techniczny melioracji użytków rolnych. (Stary Bród. Technical documentation of the analyses of ground substratum. Technical project of cropland reclamation). Mońki, Teren. Zesp. Usług Projekt.

9. KuPRYJANOWICZ M., 1991. Eemian, Early and Late Vistulian, and Holocene vegetation in the region of Machnacz peat-bog near Białystok (NE Poland) - preliminaly results. Acta Paleobot., $31(1,2): 215-225$.

10. KUPRYJANOWICZ M., 2007. Zmiany poziomu wody w eemskich jeziorach i torfowiskach północnego Podlasia. (Changes in the water level in Eemian lakes and peatlands of northern Podlasie). Prz. Geol., 55, 4: 336-342.

11. KuPRYjANOWICZ M., 2008. Vegetation and climate of the Eemian and Early Vistulian lakeland in northern Podlasie. Acta Paleobot., 48(1): 130.

12. Kupryjanowicz M., DrZymulska D., 2008. Torfowiska Puszczy Knyszyńskiej - niedoceniane archiwum wiedzy o jej przeszłości. W: Parki krajobrazowe w I połowie XXI wieku - edukacja ekologiczna wczoraj i dziś na przykładzie Parku Krajobrazowego Puszczy Knyszyńskiej. (Peatlands of the Knyszyńska Forest - an undervalued archive of its past. In: Landscape parks in the first half of the $21^{\text {st }}$ century - ecological education now and in the past based on the Landscape Park of the Kyszyńska Forest example). Eds. A. Górniak, B. Poskrobko. Supraśl, Zesp. Park. Krajobr.: 48-56.

13. MiCUN K., 1996. Utwory hydrogeniczne w południowej części obiektu melioracyjnego „Stary Bród”. W: Gleby hydrogeniczne na obszarze północno-wschodniej Polski, ich jakość i użytkowanie. (Hydrogenic formations in southern part of the reclamation object „Stary Bród”. In: Hydrogenic soils in north-eastern Poland - their quality and use). Ed. H. Banaszuk. Mater. konf. Białystok, Wydaw. Ekon. Środ.: 33-42.

14. MiCUN K., 2006. Development of the peatlands in the Czapielówka stream spring zone against the background of the Knyszyńska Forest relief. Pol. J. Env. Sci. 15, 5D: 21-25.

15. Musią A., 1992. Studium rzeźby glacjalnej północnego Podlasia. (A study on glacial relief of northern Podlasie). Rozpr. UW. Warszawa, Wydaw. UW: 203.

16. Stasiak J., 1979. Wiek Jeziora Maliszewskiego i bagien w Kotlinie Biebrzy. (The age of Lake Maliszewskie and of bogs in the Biebrza Valley). Pr. St. Inst. Geogr. UW, 23(8): 129-172.

17. ŻUREK S., 1991. Geomorfologia Pradoliny Biebrzy. (Geomorphology of the old Biebrza Valley). Zesz. Probl. Post. Nauk Rol., 372: 29-62.

18. ŻUREK S., 1992. Wyjaśnienie sytuacji chronostratygraficznej i geomorfologicznej w okolicy torfowiska Machnacz. (An explanation of the chrono-stratigraphic and geomorphological situation near the Machnacz peatland). Sprawozdania z Badań Naukowych Komitetu Badań Czwartorzędu PAN. nr 9 Warszawa: 39-50.

19. ŻUREK S., 2000. Stratygrafia, geneza i wiek torfowiska. W: Przemiany siedlisk i roślinności torfowisk uroczyska Stare Biele w Puszczy Knyszyńskiej. (Stratigraphy, origin, and the age of a peatland. In: Transformations of habitats and vegetation in the Stare Biele peatland in the Knyszyńska Forest). Ed. A. Czerwiński, A. Kołos, B. Matowicka. Rozpr. Nauk. P.Biał., 70: 40-69. 


\section{STRESZCZENIE}

\section{Utwory jeziorne w północnej części Puszczy Knyszyńskiej - pozostałości po zbiornikach wodnych}

Słowa kluczowe: gytie, późnoplejstoceńskie pojezierze, Puszcza Knyszyńska, torfowiska

W artykule przedstawiono wyniki badań litologicznych i geomorfologicznych przeprowadzonych w północnej części Puszczy Knyszyńskiej. Celem badań było rozpoznanie rozprzestrzenienia utworów jeziornych, występujących pod współczesnymi torfowiskami. Na tej podstawie odtworzono rozmieszczenie i zasięg zbiorników wodnych w późnym plejstocenie i wczesnym holocenie na tle uwarunkowań geomorfologicznych.

Stwierdzono stosunkowo powszechne występowanie utworów jeziornych w dnach obniżeń w północnej części Puszczy Knyszyńskiej. Występują one w górnych fragmentach zlewni Czapielówki, Jałówki, środkowej Sokołdy, w rejonie Czarnej Białostockiej oraz dalej na północy, w zlewni górnej Kumiałki. Miąższość gytii wynosi od 0,4 do $2,5 \mathrm{~m}$. Są to gytie detrytusowe, węglanowe i ilasto-wapienne. Utwory jeziorne zalegają $\mathrm{w}$ dnach różnego rodzaju obniżeń wytopiskowych. Genezę wytopisk, jak i całej rzeźby glacjalnej tego terenu, łączy się najczęściej z zanikiem lądolodu zlodowacenia Warty. Jednak wiek utworów kemowych w Janowie, nawiązanie rzeźby do niższych, młodszych poziomów morfologicznych oraz występowanie bezpośrednio pod osadami jeziornymi utworów ablacyjnych i zwałowych przemawiają za młodszym wiekiem wytopisk położonych w zlewni górnej Kumiałki.

Received 20.07.2009

Reviewers:

Prof. Zbigniew Kowalewski

Prof. Czestaw Szafrański 